\title{
Effects of Empowerment on Employee Burnout and Performance: Case of Mulago National Referral Hospital
}

\author{
Halima Kibirige ${ }^{1}\left(\mathbb{D}\right.$, Aysen Berberoglu $2^{*}$ \\ ${ }^{1}$ Cyprus International University, Nicosia, Cyprus \\ ${ }^{2}$ University of Mediterranean Karpasia, Nicosia, Cyprus \\ * Corresponding author: Aysen Berberoglu E-mail: aysen.berberoglu@gmail.com ORCID: 0000-0003-0073-9035 \\ Received: 08 December 2017 Accepted: 08 January 2018
}

\begin{abstract}
The study was intended to investigate the effect of empowerment on employee burnout and performance. The objectives of the study were to determine the relationships between employee burnout and employee performance at Mulago National Referral Hospital, to determine the relationship between employee empowerment and employee performance at Mulago National Referral Hospital and to establish the extent to which Mulago National Referral Hospital has put in place employee empowerment programs. In reference to the methodology used, the research was conducted using quantitative approach as Research Design. Data was collected using different Questionnaires as well as review of available documents and records. Data was analyzed using tally and frequency tables where conclusions were drawn from. The research findings showed that there was a connection among burnout and work execution. The outcomes affirmed that worker burnout may influence execution. Respondents who were sincerely depleted and depersonalized would in general have low execution, while the individuals who detailed high close to home achievement would in general be superior workers which were represented by estimation of the co-efficient as equivalents to 0.136 . It was further revealed that there was no connection among strengthening and worker execution. In light of this, it ought to be noticed that representatives' not generally on agreement of the degree in which worker strengthening practices was being utilized. This was represented by estimation of the co-efficient as equivalents to -0.052 . The research concluded that taking everything into account, giving employees scope by designating specialist and basic leadership can enable them to feel engaged, which can improve execution, just as responsibility. As a proprietor, in a perfect world you need employees who can think and follow up on their own, inside specific rules, so you don't generally need to look out for their shoulder to ensure work completes appropriately.
\end{abstract}

Keywords: empowerment, burnout, employee performance

\section{INTRODUCTION}

This study investigated the outcomes of empowerment on employee burnout and performance. It intention consider man burnout or empowerment as the based unstable (DV) yet performance so the unbiased unstable (IV). This book introduces the foundation over the investigation, bother proclamation, yet reason over the examination, novel goals, inquire about inquiries, theory, and afterward scope over

@ 2020 by the authors; licensee EJMETS by Bastas, UK. This article is an open access article distributed under the terms and conditions of the Creative Commons Attribution License (http://creativecommons.org/licenses/by/4.0/). 
the examination, applied edge just as the operational definitions.

\section{Background of the Study}

The historical past about this work is introduced namely as historic background, theoretical history, conceptual historical past, then the to the purpose heritage for outcomes concerning empowerment and employee burnout on performance.

\section{Historical Background}

Verifiably, servant empowerment is a resolution TQM object to those amount administrators is counted over in accordance with construct the success regarding TQM execution. That is of the grounds up to expectation TQM accentuates of the road over life of such as entire employees all the whilst yet including in accordance with the job execution improvement [1]. Worker empowerment has been linked including the unmistakable multiplication about association's characteristic way of life [2]. Subsequently, out of administrative appreciation point regarding view, enabling worker prompts accomplishes the best about TQM execution. Using yet revelation the empowerment rehearses internal the government technique among affiliation incites and requires the idea about whole abroad employee empowerment [3]. They further contend that the idea of absolute employee empowerment has an astounding commitment to the supervisors' understanding and attention to TQM. Besides, their finding showed that empowerment society inside the worldview of TQM rehearses in improves the results of the TQM framework.

Empowerment has turned out to be a standout amongst the most remarkable ideas in present day, the board hypothesis and practice. Definitions fluctuate, yet for the reasons for this investigation, empowerment is characterized as: the way toward furnishing workers with the important direction and aptitudes, to empower self-governing basic leadership (counting responsibility and the duty) for settling on these choices inside satisfactory parameters that are a piece of an authoritative culture.

Essentially, Vogt [4] characterized empowerment as the demonstration of allowing individuals the chance to settle on work environment choices by extending their selfgovernance in basic leadership. Empowerment likewise has been portrayed as the separating of conventional various leveled structures, as in an enabled association, the line faculty nearest to an issue, are given the expert to take care of the issue [5]. The idea has crossed societies and mechanical parts.

Spirits [6] for instance, has cited a kindred Mexican, Freddie Lopez, as proposing that empowerment is preparing employees to offer each other trust, support, instruction, thoughts, regard and inspiration with the point of building up every individual's abilities. Lopez likewise remarked that empowerment must be a procedure and a long haul duty that is joined into an organization's development system, in order to persuade and to breed faithfulness among specialists. In reality, employees who have self-governing basic leadership abilities can go about as colleagues, keeping watch on productivity [7].

From an administration viewpoint, empowerment gives employees the expert to settle on choices concerning client administration. Genuine empowerment implies that employees can curve and disrupt guidelines to do whatever is important to deal with the client [8]. As it were, empowerment is the "insight to realize what to do, the will to do what should be done, and the fortitude to do it" [9].

Leitch et al. [10] portrayed employee empowerment as "the significance of giving employees both the capacity and the obligation to find a way to distinguish issues in the workplace that influence quality or client administration and to manage them". As indicated by Argyris [11, p. 102-123], a CEO once stated, "No vision, no system can be accomplished without capable and engaged employees". Besides, enabled employees are ideal as well as fundamental to execute the association's objective to be financially solid and earth dependable [12].

The presentation of another program will yield ideal outcomes when employees are treated as real partners in an association [13]. Enabled workers are roused and resolved to take an interest and take part in improving the organization execution. Employees who are not enabled have less duty for development than the engaged workers [11]. The board can energize worker empowerment by changing the authoritative structures that help empowerment [10]. One way to that amount regimen may energize employee empowerment is via changing the kind of the association. The normal pinnacle below affiliation restrains worker empowerment; rather, a compliment, too affiliation obligation in accordance with is put in on after support man empowerment.

Organizations need to move to a progressively open type of participative administration so as to enable their workers [14]. Laborers can contribute all the more viably when the 
executives moves the choice shut down to the employees, permitting them the opportunity and capacity to make recommendations and actualize great business rehearses [15].

Enabled employees who have independence and basic leadership control are additionally bound to be increasingly engaged with the improvement of the earth. Employee association (EI) can be depicted as "a participative procedure to utilize the whole limit of specialists, intended to urge worker pledge to authoritative achievement" [16]. Also, Enander et al. [12, p. 5-7], trust worker contribution may influence social change and fundamentally decrease poisons at their beginning spot. Since a considerable lot of the endeavors in contamination avoidance depend on employees working and connecting with different divisions, worker contribution turns into a need to improve chances for progress.

Employee inclusion as quality circles enables various aptitudes to be tapped support a proportion of straightforward fun, and it gives a crowd of people to the show of powerful execution [17]. Everybody in the association through and through, from workplaces to specialized administration, from central command to neighborhood locales must be included. Individuals are the wellspring of thoughts and development and their skill, experience, learning and co-task must be outfit to get these thoughts actualized [18].

\section{Theoretical Background}

Different theories have been devoted to assist deliver readability in accordance with the discipline about the outcomes over worker empowerment over burnout and performance. This work borrows from the theory over structural theory over empowerment according to construct the essential worries about results of man empowerment on burnout yet performance.

\section{Structural Theory of Empowerment}

The exploration will utilize the basic hypothesis of empowerment which has been recognizing by Kanter [19]. Kanter hypothesis of basic empowerment attested that the structure of the workplace is a significant associated of worker mentality and conduct in associations and see access to power and opportunity structure identified with the conduct and dispositions of employees in associations. Kanter prescribed that the individual grandstand different lead dependent upon whether certain assistant assistance (power and opportunity) were set up. The fundamental part is Opportunity; insinuates advancement, adaptability, and the chance to construct data and aptitudes. Second Structure of power; suggests the ability to get to and get ready resources, information and support from one's circumstance in the relationship to put everything in order successfully. Access to assets implies the capacity to get essential materials, supplies, cash, and work power expected to meet different leveled targets. Information relates to the data; specific learning and authority require playing out one's occupation. Support suggests bearing and information get from subordinate, companions, and boss to overhaul feasibility. The hypothesis obviously delineate that, when duty are assigned to employees it will altogether help specialists so as to improve their execution and furthermore to meet to anticipated objectives of the association.

\section{Conceptual Background}

The idea of worker support has been amount for analysis and applies for an extended time. It is taken varied structures, developing through the employee contribution and participative basic leadership concepts into the up to date authorization purpose of read. The thought of authorization includes the work force being supplied with a additional noteworthy level of ability and additional chance to decide on selections distinguishing with work. These balance notably with typical administration ways that have stressed management, hierarchy and inflexible nature. The importance of authorization has would normally be connected with the thought of intensity, during this approach suggesting force is decentralized by those during a senior position to those in an ever increasing number of subordinate positions [20]. Whereas their area unit records of the alleged focal points of authorization, regardless it remains associate inadequately characterized plan that is each currently and once more utilized during a logical sense [21]. Authorization is that the approach toward empowering or approving someone to assume, carry on, create a move and management work and basic leadership in independent ways in which. It's the condition of inclination bound to assume responsibility for one's terribly own predetermination [22].

The importance of authorization has been the topic of unbelievable discussion nevertheless at identical time remains inadequately characterized [23]. Mondros et al. [21] and Russ et al. [24, p. 29-31] correspondingly contended that the term is once whereas characterized signally and is routinely utilized logically. One possible reason behind this nonappearance of clearness is that the affinity for approval to be associated with the officials' ideas, for instance, business strategy re-building (BPR) and each one out quality organization (TQM) [23]. In addition, the term approval 
addresses a decent combination of activities, from "fabrication" approval [25] to relate strange condition of affiliation and devolution of force. Sir Geoffrey Wilkinson (1998) perceived 5 kinds of strengthening: data sharing; upward significant reasoning; task self-rule; attitudinal embellishment; and self-organization.

Affiliations are dynamically looking strengthening as an exceptional asset that can improve execution and give bolstered advantage. The modifications in the business condition with growing globalization, changing economics of the workforce, extended focus on advantage through advancement; imaginative changes, insightful capital and the unlimited changes that affiliations are encountering have provoked extended hugeness of laborer strengthening [26]. For any relationship to work beneficially and satisfactorily, different resources must be used. For example, physical workplaces like structure, equipment; budgetary resources and HR.

Thought of any advancement in an association, the segment human capital is exceptionally pivotal for any important improvement in an association. For instance to build profitability you need to manage individuals and to expand productivity you have to deal with the frame of mind and abilities of your employees. Accordingly for individuals to perform well they must be empowered through aptitudes improvement and helpful condition for learning and advancement [26].

Everybody in the association through and through, from workplaces to specialized administration, from central station to neighborhood destinations must be included. Individuals are the wellspring of thoughts and advancement and their mastery, experience, information and participation must be bridled to get these thoughts actualized [18]. Workers are the center elements of administration items. Since insignificant time isolates the creation of the administration from its conveyance, giving specialists the adaptability, scope, and capacity to satisfy client administration needs is naturally engaging; in this way it isn't astounding that increasingly more administration associations are grasping worker empowerment programs [27].

Employee burnout is a condition of physical, passionate, and mental weariness that is described by physical exhaustion, sentiments of vulnerability and sadness, and enthusiastic channel, just as trouble, discontent, and sentiments of disappointment in the quest for standards. Besides, burnout makes pessimistic self-ideas and antagonistic dispositions towards work, life, and other individuals [28].
Components identified with burnout incorporate individual factors, for example, age, training, residency and working hours, alongside authoritative factors, for example, deficient acknowledgment and, open door for advancement, dissatisfaction as to one's very own desires, weight concerning customers' improvement, accessibility of assets, group like hierarchical structures, a tribe culture, and transformational and value-based initiative [29].

Moreover, inert bureaucratic situations were found to add to burnout and burnout is identified with lacking self-rule in utilizing learning and aptitudes to play out one's occupation [28]. Thus, absence of power over one's work was accounted for as an indicator of burnout. Likewise, an absence of selfrule has been observed to be firmly identified with burnout. Since administrations will in general have encircled expert, descending channels of direction, specialization, and formal responsibility and chain of importance, all of which lessen workers' independence and control, they tend to increment burnout [28].

Alternately when workers are permitted to take an interest in basic leadership about issues that influence them through just styles of administration, they appreciate abnormal amounts of occupation fulfillment and lower dimensions of burnout [30]. Employees are engaged in occupations where they are upheld and empowered by the association's initiative to have a functioning job in authoritative change, an abnormal state of worker command over their workplace, and the chance to take an interest in basic leadership process [31]. Employees need to get to learning and data important to do their occupations; get bolster, for example, input from other individuals whom they work with; and procure material, cash, and rewards vital for achieving the requests of the activity to be enabled [32], while burnout creates when workers see their associations to underestimate them and their innovativeness, work, commitment, or development. One impact of this discernment is that employees who are incredibly depleted will in general be at a more serious danger of displaying estrangement, disengagement, absence of inspiration, and negative viewpoint toward the association [31].

\section{Contextual Background}

All affiliations intend to make a workplace where representatives truly care about the results the affiliation conveys and feel duty regarding with the true objective that they industriously try to improve them. This attitude and style of definitive activity has been called drawn in workplace [33]. Thusly, empowerment of authorities is one of the organization methodologies used by associations on 
account of the need of get-together a better test world and then hold representative from discovering work somewhere else. Empowerment accepts gigantic occupation in representative's satisfaction as needs be propelling their execution in affiliations.

Wellbeing administration is fundamental to financial advancement and nature of wellbeing administrations of any nation depends to a huge degree on the worker execution [34]. Glad [35] affirmed that the nonappearance of worker execution in many clinics is ascribed to absence of employee empowerment, trust and commitment. In Uganda, the idea of empowerment in the work place has turned into a noteworthy topic in many associations today.

Mulago National Referral Hospital, normally known as Mulago Hospital, is a medical clinic in Uganda. It is the biggest open emergency clinic in the nation, with 1,500 beds. In 2014, midpoints of 80 to 100 infants were conveyed every day, in the clinic's three maternity wards. It is likewise one of the two national referral medical clinics in the nation, the other one being Butabika National referral emergency clinic. The clinic offers benefits in most therapeutic and careful sub-claims to fame, notwithstanding dentistry, crisis medication, pediatrics and concentrated consideration.

At Mulago Hospital empowerment is taken into high thought for employees so as to improve their execution. In Mulago Hospital more measures have been set up to guarantee they improve in their execution. Fitting empowerment of workers at the medical clinic appears to offer the cost of creating sentiments of commitment to the administration experience and opportunity to utilize that capacity to address client issues that emerges. Be that as it may, in spite of the commitment of workers empowerment towards burnout and execution, Mulago Hospital displays debilitation, doubt and withdrawal condition which has prompted proceeded with nonappearance of employee execution, subsequently influences the nature of wellbeing administrations.

Given the criticalness significance of empowerment, there is a direness in distinguish the effect of empowerment towards worker execution and burnout and this investigation likewise looked at the impacts of employee empowerment on the burnout and execution taking Mulago Hospital as the contextual analysis.

\section{Statement of the Problem}

Acknowledgment of the productive utilization of the HR for business achievement together with advances in social majority rules system has offered ascend to representative empowerment in upgrading worker execution. Perceiving that work power has changed and the present laborers are far superior taught and prepared, learned about their occupations, multifaceted nature of numerous occupations, worldwide aggressiveness where associations must move quick and the impact of destroying associations chains of importance [36], there is more prominent want with respect to representatives to assume a functioning job in choice and exercises that influence them. It might be sensible to presume that the long haul pattern will learn towards a more prominent level of representative empowerment.

In quest for better execution, most associations like Hospitals are setting up representative empowerment programs which are gone for making a connection between business targets and individual goals. The real issue that numerous associations have is the manner by which far to enable representatives since many dread losing a significant level of capacity to the workers.

Associations are at various dimensions of worker empowerment with not very many having accomplished full empowerment. Japan is referred to as a genuine case of representative empowerment rehearses with the most regularly imitated empowerment strategies having the quality circles, cooperation in monster organizations, for example, Hitachi, Nissan, Honda, Mitsubishi and Toyota [37].

A large portion of the investigations on empowerment demonstrate that there is a logical inconsistency between what representatives and the board need from worker empowerment activities and what the executives are set up to permit the workforce as far as empowerment and control. Engaging workforce means enabling them to partake in basic leadership, communicating trust in their capacity to perform at abnormal states, structuring their occupations so they have more prominent opportunity, defining definitively and testing objectives, cheering exceptional execution can urge workforce to assume individual liability for their work.

Besides, stress and burnout have been appeared to build the use of debilitated leave, to add to at work mishaps, and broaden worker turnover (Survey of Organizational Excellence, 1996). Studies demonstrate that representatives with burnout issues are bound to have higher nonappearance rates, perform second rate work, and commit exorbitant errors [38].

Tsala [39] led an exploration on the connection between representative empowerment and execution at the city gathering of Nairobi and discovered that there was 
connection between worker empowerment and execution. Lwangasi [40] completed an overview on the connection among empowerment and occupation fulfillment on the representatives in non-legislative segment in Kenya which demonstrated that there was a huge connection between the two factors. From the previously mentioned investigations there is clear sign that most examinations were not completed from Uganda and none of this examination center around open clinics. This investigation looked to decide with the impact of worker empowerment on burnout and execution in open medical clinics taking Mulago referral Hospital as the contextual analysis.

\section{General Objective}

The major objective of the study was to establish the effect of empowerment on employee burnout and performance at Mulago Referral Hospital.

\section{Specific Objectives}

The objectives of the study are;

a) To determine the relationships between employee burnout and employee performance at Mulago Referral Hospital

b) To determine the relationship between employee empowerment and employee performance at Mulago Referral Hospital

c) To establish the extent to which Mulago Referral Hospital has put in place employee empowerment programs

\section{Research Questions}

a) What is the relationship between employee burnout and employee performance at Mulago National Referral Hospital?

b) What is the relationship between employee empowerment and employee performance at Mulago National Referral Hospital?

c) What is the extent to which Mulago National Referral Hospital has put in place employee empowerment programs?

\section{Hypothesis of the Study}

The following hypotheses are to be tested in this study;

$\mathbf{H}_{\mathbf{1}}$ Empowerment has a relationship with employee performance.

$\mathbf{H}_{\mathbf{2}} \rightarrow$ Employee burnout has a relationship with employed performance
$\mathbf{H}_{\mathbf{3}}$ Empowerment has an influence on employee performance.

$\mathbf{H}_{4}$ Employee burnout has an influence on employed performance

\section{Significance of the Study}

The discoveries of the investigation will straightforwardly profit the open emergency clinics since the administration will start representative empowerment programs which will eventually bring about improving worker execution as far as conveyance of powerful and productivity administrations to the colossal customer in their territories of locale.

The examination may have an incentive to the legislature as far as thinking of approaches to deal with their HR and guarantee representative responsibility in open associations. The administration has utilized methodologies incorporating staff justification in an offer to guarantee quality administrations to people in general. Anyway, these have accomplished negligible outcomes subsequently calling for new measures. Submitted workers are performing representatives in this way measures ought to be set up to guarantee representative responsibility. The outcomes from this examination may advise the administration on such estimates that can be taken to get changes the open part.

The suggestions given toward the finish of study will help the Ministry of wellbeing in supporting the worker empowerment projects bringing about improved administration conveyance; high efficiency in the wellbeing division. The overall population will profit through improved administration conveyance because of a superior roused wellbeing division workforce. The investigation will utilized as a source of perspective point for future specialists in the field of representative empowerment.

\section{Justification of the Study}

During recent years, our country's health sector has had massive transformations. The competition between the different health centers becomes more intense every day. Private and public hospitals as well as medical clinics try to gain larger shares of the market. Therefore, they seek to devise better methods to provide more diverse services and attract more customers and increase their profitability. Yet, most of them are unaware of an element which can become their competitive advantage. Human resource and organizational performance improvement is the missing links in achievement of health sector' goals. In fact, motivated and unified employees are the key to a hospital's prosperity or its demise. Therefore, proper attention to 
employees in order to cultivate capable, eager, dynamic, and creative workforce can lead any hospital to success [38].

A person's self-image is one of the fundamental and important subjects of psychology which can set the background for social and educational achievement, while being affected by it as well. There is also an interaction between attitude and learning. Most theories on achievement motivation consider individuals' beliefs to be the most important factor contributing to their progress. In fact, all of these theories presume that individuals' expectations and perceptions of their own abilities play an important part in their motivation and behavior. Also, perception of incompetence in a situation creates more pressure than the quality of that situation. Individuals with low self-efficacy have pessimistic views on their own abilities and stay away from any situation that they consider to be beyond their capability. On the other hand, individuals with high self-efficacy consider hard tasks as challenges which they can overcome [39].

Requirements and conditions for improvement of selfefficacy should be provided. To this end, psychological empowerment is a beneficial factor. On that basis, cultivation of employees with self-management abilities has introduced human resource empowerment as a new paradigm which attracts many experts of management [38]. The present research helps stakeholders and authorities to take empowerment and constant control of its indices in Mulago National Referral Hospital into consideration and use those factors to improve the organizational performance. Therefore, considering the importance and necessity of employee empowerment and regarding the impact of employee performance, the present research studies the impact of empowerment on burnout and performance.

\section{RESEARCH METHODOLOGY}

This part reaveals the exploration measures to be utilized in the investigation. It further uncovers the information sources, instrument of information gathering and information investigation to be utilized in the examination.

\section{Research Design}

Quantitative strategy was utilized; this is a technique whereby questions were coordinated to individuals utilizing a poll. When the inquiries are replied, reactions gotten are then examined by the researcher. The work pointed towards addressing the essential inquiries that each worker is gone up against with identifying with the effects of empowerment on employee burnout and performance.

\section{Study Population}

The target population was employees of Mulago National Referral Hospital who included Nurses, Doctors, clinical officer and administrators at the study site who were purposively selected. These totaled to 240 employees.

\section{Sample Size}

The overall sample size constituted of 148 respondents derived from a total population of 240 employees of Mulago National Referral Hospital. This sample size is determined using Krejcie's formula.

In order to determine the sample size, Krejcie's formula was applied [41].

\section{Sampling Technique}

Sampling is characterized as a method of choosing an appropriate example to decide parameters or qualities of the entire populace [44]. The investigation applied purposive sampling method because of the characteristics the source has. The scientist picked what should be known and embarks to discover individuals who can and are anxious to give the data by temperance of data or experience.

\section{Data Sources}

Primary and secondary sources was utilized.

\section{Primary data}

This alludes to crude information gathered on source which has not been exposed to handling or some other control. Essential information was gained from respondents by administering of surveys to individuals of chose test, and view of the example of events in the Mulago Referral Hospital. This is in light of the fact that essential data is progressively strong, up to date and from the most reliable source.

\section{Secondary data}

This is the type of data that has been already collected and readily available from other sources. This includes data from the internet, text books, journals and publications.

\section{Methods of Data Collection}

\section{Questionnaire method}

The data was assembled with help of self-regulated surveys. The inquiries in the poll were founded on the exploration destinations to guarantee that the point of the investigation is accomplished. The polls included 5-point Likert scale estimation. A likert scale was used when reacting to a poll 
Table 1. Showing Validity and reliability

\begin{tabular}{|c|c|c|}
\hline Variable & No. of Items & Cronbach's Alpha \\
\hline Instrument Validity & 6 & 0.706 \\
\hline Burnout & 7 & 0.799 \\
\hline Empowerment & 7 & 0.799 \\
\hline Employee performance & 6 & 0.769 \\
\hline
\end{tabular}

whereby respondents decided their dimension of comprehension or logical inconsistency to an announcement. This technique comprised of solid and steady, short and brief inquiries and proclamation that was issued and circulated among the respondents to "tick mark" from the size of (Strongly Agree SA; Agree A; Not certain N; Disagree D; and Strongly Disagree SD) the most suitably coordinating scale and they filled in the required data. This method was used because it is convenient especially for respondents who do not want to be interviewed directly and it is time saving given the short period of the study. The statements in the questionnaire are written in reference to Tsala [39] and Kimanzi [43].

\section{Reliability and Validity of Information}

\section{Validity}

According to Amin [44] validity refers to the appropriateness of the instrument, thus the degree to which an instrument measures and what it is supposed to measure. In order to emphasize validity, the questionnaires were constructed according to research objectives which were validated by the supervisor and two other experts in order to get expertise judgment on the content validity to ensure that the questions are capable of capturing the intended data. This was also done to help improve the sentence construction and language clarity of the data instruments based on the comments that was obtained from those who reviewed the instruments.

\section{Reliability}

Mugenda et al. [45] defined reliability as the instrument's consistency in measuring whatever it is intended to measure. The study tested for reliability coefficient basing on Cronbach's Alpha method for reliability and content validity index. All the values for reliability coefficients were exceeding 0.7 implying that these results were very reliable and consistent. In the same way, the content validity index values exceeded 0.7 implying that the study yielded valid results as indicated in Table 1.

According to Trochim [46], the shorter the time span, the higher the relationship, while the more drawn out the timeframe the lower the relationship. The feedback from

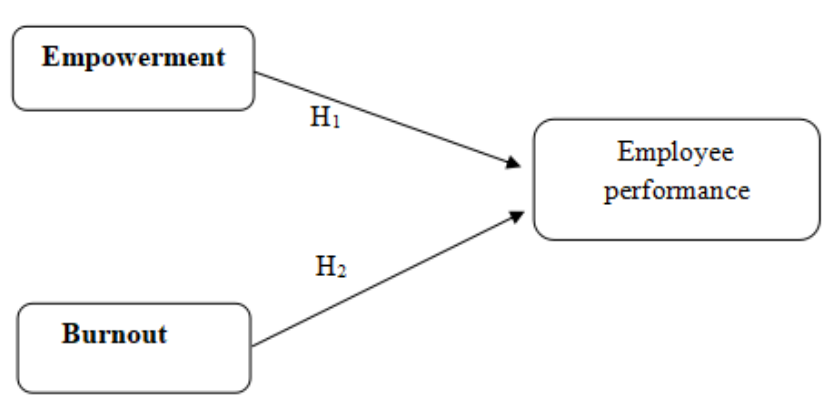

Figure 1. Research Hypothesis Model

their responses was used to improve the final questionnaire. To further ensure reliability of the study, adequate training of enumerators will be conducted prior to the actual survey.

\section{Model of the Study}

The hypothesis of study is shown in Figure $\mathbf{1 .}$

The dependent variables are empowerment and burnout. The independent is employee performance.

\section{Empowerment}

The Empowerment thought was got from the Theory of Kanter. As demonstrated by Kanter [47], formal and easygoing courses of action are two wellsprings of Empowerment. The basic components of the formal power are work judiciousness, thankfulness and significance with the goals of the affiliation. The component of occupation thoughtfulness licenses versatility, alteration and imaginativeness in work. The segment of affirmation imitates detectable quality of master's accomplishments among accomplices and boss. At long last, relevance to the action insinuates the commitments and accomplishments of imperative plans and destinations of the affiliations. The other key fundamental structure of the workplace Empowerment is easygoing force that diverts out from agents' associations building and organization inside the affiliation and outside. Strengthening is a key factor of legitimate and various leveled ampleness and has all the earmarks of being major for both the measurements; individual similarly as definitive [48]. One noteworthy result of engaging representatives is the identification of essentials which energizes and encourages the endeavors relating to the working environment Empowerment; these are otherwise called predecessors of auxiliary Empowerment [47] like data and correspondence assets, impetuses and rewards, alludes to the arrangement of occupation performance based prizes to the workers, selfrule implies one might be enabled to take choices without endorsement from others, abilities and information allude to the representatives being outfitted with full learning and 
aptitudes about their activity, confidence incorporates general assessments about self-esteem as representatives having high confidence take part more in the work environment when contrasted with workers with low confidence. Based on the abovementioned, the accompanying speculation will be tried:

$\mathbf{H}_{\mathbf{1}}$-mpowerment has a relationship with employee performance.

\section{Employee burnout}

The possibility of laborer burnout ascended during the 1970s, and still continues at this moment. It was first introduced by Herbert Freudenberger, a psychoanalyst working in an office in New York [49]. Laborer burnout stems on account of steady occupation weight that isn't reasonably dealt with. It is a psychological response to the movement stress that impacts work execution, yet what's more makes low progressive obligation [50]. The state of burnout was seen among agents when the business world started surrendering present day part to help zone [51]. Agent burnout is broadcasted to be a word related hazard and is found in the two individuals and affiliations. It has been seen that movement burnout reduces mental and physical element of imperativeness [52]. It obviously is reduced or extended in view of individual and various leveled weight part. It happens because of various variables both ecological and individual in nature. The ecological variables are substantial remaining task at hand, control, proprietorship, grants, qualities and equity and individual elements are character, profitable dimension, desires, control center, and statistic Features [53]. Representative burnout emerges because of developing variable of depersonalization, mental fatigue, and bringing down feeling of individual achievement [54].

On the basis of the above, following hypothesis will be tested:

$\mathbf{H}_{\mathbf{2}} \rightarrow$ Employee burnout has a relationship with employed performance

\section{Employee performance}

Laborer execution is seen as a total a motivation to any affiliation. It is a mix of practices of a laborer who contributes both authentically and by suggestion to achieve legitimate targets [55]. It is in like manner described as the ordinary yield from the agents' practices which is done over a predefined time period. It is considered as results accomplished as in an eventual outcome of playing out a development or limit dictated by the arrangement of working obligations [56]. Nonetheless, work execution depends on amalgamation of limits and motivations work execution is assessed similar to results, figuratively speaking. Every action limit is assessed by six unique ways: sum, worth, cost ampleness, necessity for seniors, common sense, and social impact [57]. Some out of the above estimations may have no noteworthiness with all action works out. Bernardin [56] underscore the essential to know the associations among these six segments of occupation execution; for instance, a movement done in reasonable quality and sum yet not inside stipulated time schedule presumably won't be worthwhile for affiliation. Campbell [58, p. 169-177] explains the covert improvement of business execution with eight estimations which are: work unequivocal errand capacity, non-work express endeavor ability, oral correspondence and created correspondence, tries to delineate, discipline upkeep, help for partners and gathering results, control, and the administrators. Representative explicit assignment suggests how much the specialist can execute the middle substantive endeavors that remember one work from other. On the other hand non-work explicit errand insinuates assignments those are not shown for a specific occupation, and expected every one of the partners of the business setting. Showing tries spread dauntlessness and nature of delegate to complete the movement. Association/the administration vary from control; the board means planning and managing the endeavors of business, which is specific from authoritative employments. The correspondence whether it may be oral or made exhibits the bent and mirrors a noteworthy factor of work execution. In light of the above mentioned using regression, the elective hypothesis would be:

$\mathbf{H}_{\mathbf{3}}=$ Empowerment have an influence on employee performance

$\mathbf{H}_{\mathbf{4}}=$ employee burnout has an influence on employee performance

\section{Data Analysis}

Following information is gathered, the analyst altered the discoveries by checking the exactness of the information. This assisted the specialist with getting the right data toward the finish of the investigation. This included the examination of the variety because of the inquiries as indicated by the respondent, at that point quantitative information was dissected utilizing Statistical Package for Social Sciences (SPSS adaptation 17) to comeup with the exploration finding. While subjective information was investigated in relationship to the writing audit in part two. The analysed data was interprited in respect to the set objectives in 
Table 2. Response Rate

\begin{tabular}{|c|c|c|c|c|c|c|}
\hline Response Rate & \multicolumn{2}{|c|}{ Expected Response } & \multicolumn{2}{c|}{ Actual response } & \multicolumn{2}{c|}{ Non response } \\
\hline & Frequency & Percentage & Frequency & Percentage & Frequency & Percentage \\
\hline & 148 & $100 \%$ & 140 & $94.6 \%$ & 8 & $5.4 \%$ \\
\hline
\end{tabular}

chapter one using frequancy and percentages to comeup with the findings.

\section{Ethical Consideration}

Moral examinations were managed by the scientist through preparation the respondents about the motivation behind the investigation, their pertinence in the exploration procedure, and desires from them. Studies were created so that there is no notice of the respondents' names to demand to security, as were unequivocally imparted in the survey. Responding was discretionary, fundamentally clarifying the purpose for overriding respondents who were not willing to react.

\section{DATA ANALYSIS AND DISCUSSION}

This part introduces the examination and talks about the discoveries of the investigation entitled "effects of empowerment on employee burnout and performance." During the introduction, both rate and frequencies were exhibited through tables to clarify the discoveries. The information gathered was factually investigated utilizing SPSS form 17. Unmistakable insights were utilized to delineate respondents' statistic attributes. Different Regression examination was utilized to decide the impact of representative burnout and empowerment on performance. Pearson correlation investigation was utilized to assess the connection between worker burnout and empowerment on performance. In this section the accompanying measurable systems for the examination of the information accumulated for the present investigation are enlightening investigation and inferential insights.

\section{Response Rate}

The scientist focused on an sample size of 148 respondents, from whom 140 (94.6\%) had the option to completely react to the inquiries posed in the information gathering instruments and just 8 (5.4\%) didn't due their bustling timetable along these lines making the examination legitimate. As indicated by Mugenda [59], reaction rate alludes to rate subjects that react to the exploration instrument. A reaction rate of half is regarded sufficient for examination and detailing, a reaction rate of $60 \%$ is great and a reaction rate of $70 \%$ and over is viewed as generally excellent. In the light of this, the examination is esteemed to have given a predominant poll reaction rate.
Table 3. Demographic Characteristics of respondents

\begin{tabular}{|c|c|c|}
\hline \multirow[t]{2}{*}{ Demographic characteristic } & \multicolumn{2}{|c|}{ Response } \\
\hline & Frequency & Percentage \\
\hline \multicolumn{3}{|l|}{ Gender } \\
\hline Male & 55 & $39.3 \%$ \\
\hline Female & 85 & $60.7 \%$ \\
\hline \multicolumn{3}{|l|}{ Age bracket } \\
\hline $18-25$ years & 15 & $10.7 \%$ \\
\hline $26-38$ years & 73 & $52.1 \%$ \\
\hline $39-50$ years & 33 & $23.6 \%$ \\
\hline Above 50 years & 19 & $13.6 \%$ \\
\hline \multicolumn{3}{|c|}{ Period working with Mulago National Referral Hospital } \\
\hline Less than a year & 5 & $3.6 \%$ \\
\hline $1-7$ years & 40 & $28.6 \%$ \\
\hline $8-10$ years & 65 & $46.4 \%$ \\
\hline above 10 years & 30 & $21.4 \%$ \\
\hline \multicolumn{3}{|l|}{ Education level } \\
\hline Diploma & 32 & $22.9 \%$ \\
\hline Degree & 73 & $52.1 \%$ \\
\hline Masters & 15 & $10.7 \%$ \\
\hline Others & 20 & $14.3 \%$ \\
\hline
\end{tabular}

\section{Background Information of the Respondents}

The researcher sought to identify the respondents by their background information which included the respondents' age, gender, level of education and period spent working with Mulago Referral Hospital as presented in Table 3.

Table 3 is a representation of gender of the respondents who were employees of Mulago National Referral Hospital. The above table shows that $60.7 \%$ of the respondents were females and $39.3 \%$ of the respondents are male. This indicates that majority of the respondents were female though the research was gender sensitive when considering views of the respondents and it was easy to access the nurses than the doctors and the administrators.

$78(52.1 \%)$ of the respondents were in the age bracket of 26 38 years, 33 (23.6\%) were of the age $39-50$ years, 19 (13.6\%) were above 50 years of age and $15(10.7 \%)$ were within a range of 18-25years and. This indicates that respondents were mature enough to answer the questions in the questionnaires which meant that the information given was reliable.

Majority of the respondents had spent a period of 8-10 years working in Mulago Referral Hospital rated at $46.4 \%$, this was 
Table 4. Correlations

\begin{tabular}{|c|c|c|c|}
\hline \multirow{2}{*}{$\begin{array}{c}\text { Employee } \\
\text { empowerment } \\
\text { programs }\end{array}$} & $\begin{array}{c}\text { Pearson } \\
\text { Correlation }\end{array}$ & $\begin{array}{c}\text { Employee } \\
\text { empowerment } \\
\text { programs }\end{array}$ & $\begin{array}{c}\text { Employee } \\
\text { performance }\end{array}$ \\
\cline { 2 - 4 } & Sig. (2-tailed) & 1 & -.052 \\
\cline { 2 - 4 } & $\mathrm{N}$ & 140 & .541 \\
\hline \multirow{2}{*}{$\begin{array}{c}\text { Employee } \\
\text { performance }\end{array}$} & $\begin{array}{c}\text { Pearson } \\
\text { Correlation }\end{array}$ & -.052 & 140 \\
\cline { 2 - 4 } & Sig. (2-tailed) & .541 & 1 \\
\cline { 2 - 4 } & $\mathrm{N}$ & 140 & 140 \\
\hline
\end{tabular}

followed by $28.6 \%$ who had spent $1-7$ years, then $21.4 \%$ who had spent above 10 years and finally those who had spent less than a year rated at $3.6 \%$. This illustrated that the majority of the respondent had enough experience to give acceptable responses to the study questions.

$52.1 \%$ of the respondents were degree holders, $22.9 \%$ were diploma holders, $14.3 \%$ held other qualification like certificates and $10.7 \%$ held masters qualification. This indicates that the respondents were elites and so had the capacity to understand the questions asked and they answered them correctly and accordingly. Educational levels were also important in trying to assess if at all they influenced the views of the respondents concerning employee performance.

\section{Inferential Analysis}

Inferential insights are measurements which are utilized to own inferential expressions about a populace. They contrast from unmistakable measurements, which portray just the information itself in factual terms. The outcomes are gotten from measurable devices. The instruments are ANOVA test, correlation examination and Regression examination.

\section{Correlation Analysis}

In this study, correlations were utilized to ascertain the relationship existing between the study variables. The correlation was distinctively helpful in order to get preliminary insights into the link between employee performance and the various independent variables. The tables below shows the relationships between the variables based on Pearson coefficient statistic.

\section{HYPOTHESIS I}

Null Hypothesis: It is observed that there is no significant relationship between Empowerment and employee performance as seen in Table 4.
Table 5. Correlations

\begin{tabular}{|c|c|c|c|}
\hline \multirow{4}{*}{$\begin{array}{c}\text { Employee burn } \\
\text { out }\end{array}$} & $\begin{array}{c}\text { Employee } \\
\text { Pearson } \\
\text { burnout }\end{array}$ & $\begin{array}{c}\text { Employee } \\
\text { performance }\end{array}$ \\
\cline { 2 - 4 } & Sig. (2-tailed) & 1 & .136 \\
\cline { 2 - 4 } & $\mathrm{N}$ & 140 & .110 \\
\hline \multirow{2}{*}{$\begin{array}{c}\text { Employee } \\
\text { performance }\end{array}$} & $\begin{array}{c}\text { Pearson } \\
\text { Correlation }\end{array}$ & .136 & 1 \\
\cline { 2 - 4 } & Sig. (2-tailed) & .110 & 140 \\
\cline { 2 - 4 } & $\mathrm{N}$ & 140 & 1 \\
\hline
\end{tabular}

\section{HYPOTHESIS II}

Null Hypothesis: It is observed that there is no significant relationship between burnout and employee performance as seen in Table $\mathbf{5}$.

Findings in relation to the relationship between burn out and employee performance, presented the value of the coefficient as equals to 0.110 . This value being also above the significant level of 0.05 implies that there was a no relationship between burnout and employee performance.

\section{Regression Analysis}

Regression was used so as to decide the degree to which strengthening and burnout can impact the presentation of employees in the investigation zone. Here it has been explored to perceive how the autonomous factors influence or impact the result of the needy factors. The term relapse is said to mean attempting to discover the connection between two factors or more. All together words, relapse can just happen where there is a physical presence of at least two factors. Where by factor $\mathrm{x}$ which is known as the autonomous variable influences the activity of variable $y$, which is the reliant variable [60].

The formula for regression is as follows:

$Y=a+b x(1)$

Where

$\mathrm{Y}=$ unknown dependent variable

$\mathrm{x}=$ known independent variable

$\mathrm{a}=\mathrm{y}$ intercept

$b=$ slope of the line

b > 0 Positive connection between the two factors, which means we can utilize autonomous variable $(x)$ to foresee variable the reliant variable $(y)$ for huge relationship 
Table 6. Anova ${ }^{b}$

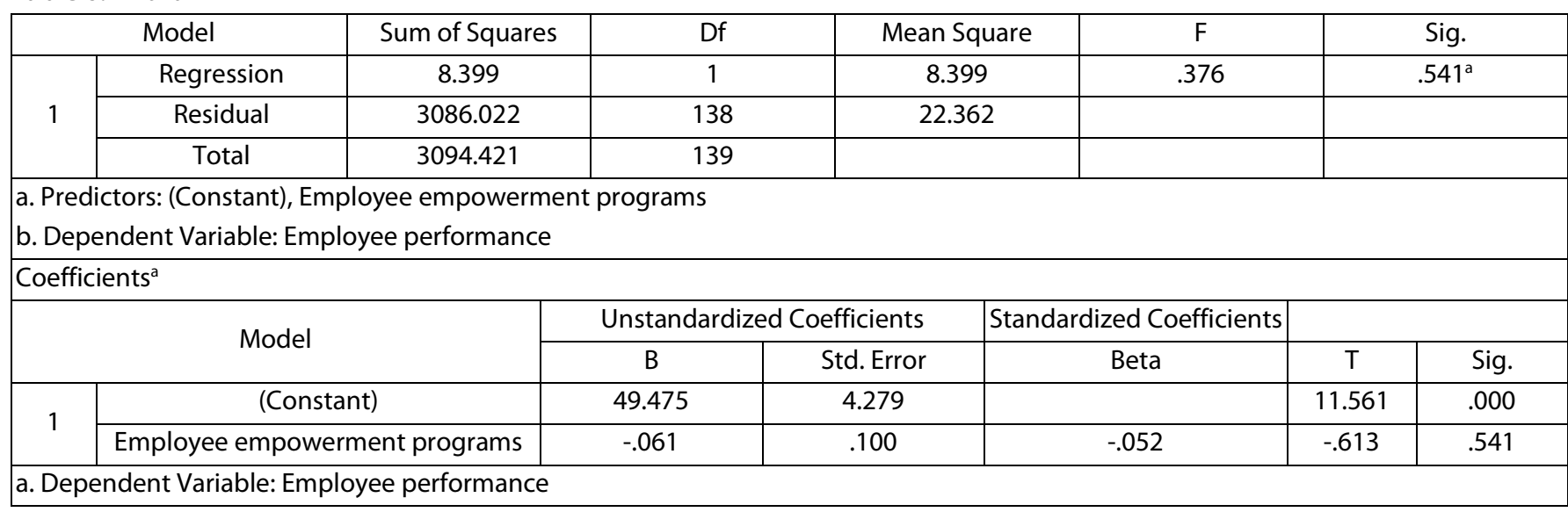

Table 7. Anova ${ }^{b}$

\begin{tabular}{|c|c|c|c|c|c|c|c|c|}
\hline \multicolumn{2}{|r|}{ Model } & Sum of Squares & \multicolumn{2}{|c|}{ Df } & Mean Square & $\mathrm{F}$ & \multicolumn{2}{|r|}{ Sig. } \\
\hline \multirow{3}{*}{1} & Regression & 56.831 & & & & 2.582 & & $.110^{a}$ \\
\hline & Residual & 3037.591 & & \multicolumn{2}{|c|}{22.012} & & & \\
\hline & Total & 3094.421 & & & & & & \\
\hline \multicolumn{9}{|c|}{ a. Predictors: (Constant), Employee burn out } \\
\hline \multicolumn{9}{|c|}{ b. Dependent Variable: Employee performance } \\
\hline \multicolumn{9}{|c|}{ Coefficients $^{\mathrm{a}}$} \\
\hline & \multirow{2}{*}{\multicolumn{2}{|c|}{ Model }} & \multicolumn{2}{|c|}{ Unstandardized Coefficients } & \multicolumn{2}{|c|}{ Standardized Coefficients } & & \\
\hline & & & $B$ & Std. Error & & Beta & $T$ & Sig. \\
\hline \multirow{2}{*}{1} & \multicolumn{2}{|c|}{ (Constant) } & 41.327 & 3.469 & & & 11.915 & .000 \\
\hline & \multicolumn{2}{|c|}{ Employee burn out } & .138 & .086 & & .136 & 1.607 & .110 \\
\hline
\end{tabular}

b $<0$ Negative connection between the factors, invalid speculation would be acknowledged no noteworthy relationship

$b=0$ no expectation win, the estimation of variable $(x)$ would be the equivalent with variable (y).

The relapse investigation was performed utilizing SPSS bundle with certainty interim degree of $95 \%$ to landing in a significant end and the outcomes are clarified underneath:

\section{HYPOTHESIS III}

Null Hypothesis: Whether empowerment has an influence on employee performance.

The result of Table 6 revealed that the null hypothesis is accepted because the value of significance is 0.541 and it's above 0.05 , there is no influence between empowerment and employee performance.

\section{HYPOTHESIS IV}

Null Hypothesis: Whether burnout has an influence on employee performance.
The result of Table 7 revealed that the null hypothesis is accepted because the value of significance is 0.110 above 0.05 , there is no influence between burnout and employee performance.

\section{SUMMARY, RECOMMENDATIONS AND CONCLUSIONS}

This chapter discusses the findings with respect to the objectives, makes conclusions based on the findings and recommendations for possible improvements with regard to the study investigating "the effect of empowerment on employee burnout and performance at Mulago National Referral Hospital."

\section{Summary Findings}

This part presents the summarized results and interpretation (findings) based on the study objectives as established at the beginning of the study.

\section{The Relationship between Employee Burnout and Performance}

In light of the investigation find in connection to the connection between burn out and worker performance, displayed the estimation of the co-efficient as equivalents to 0.136. This worth being sure infers that there was a 
connection among burnout and representative execution. The outcomes affirmed that worker burnout may influence execution. Respondents who were sincerely depleted and depersonalized would in general have low execution, while the individuals who detailed high close to home achievement would in general be superior workers. This was in relationship with the discoveries of Van et al. [61, p. 84] who attested that regarding pressure and burnout, the individuals who revealed higher burnout levels would in general likewise report high feelings of anxiety especially for measurements, for example, outstanding task at hand and vulnerability on treatment.

\section{The Relationship between Employee Empowerment and Performance}

In view of the investigation discoveries in connection to the connection among strengthening and representative execution, exhibited the estimation of the co-efficient as equivalents to -0.052 . This worth being negative suggests that there was no connection among strengthening and worker execution. In light of this, it ought to be noticed that representatives' not generally on agreement of the degree in which worker strengthening practices was being utilized. The examination demonstrated that while engaging workers were connected to great representative execution on routine assignments, there wasn't much contrast from results created from non-enabling workers. Be that as it may, there was extraordinary inconstancy. Anyway from the investigation, employees were in understanding that there was sufficient designation of power by bosses and what's more workers concurred that there was great working relationship among the employees and that the vast majority of the work targets were accomplished through collaboration. Dubrins [62] recommended that to encourage cooperation, the board ought not micromanage groups rather supervisors should show regard to the group.

\section{The Extent to which Mulago National Referral Hospital has put in place Employee Empowerment Programs}

The investigation looked to build up the degree to which Mulago National Hospital had set up worker strengthening projects and it was uncovered that the employees have had the option to ace the abilities essential for their activity and that their work is important to them. These are the most significant parts of a set of working responsibilities; a representative must have the essential aptitudes, information and comprehension of the activity jobs and desires to have the option to be given expert with least supervision.

\section{CONCLUSIONS}

Taking everything into account, giving employees scope by designating specialist and basic leadership can enable them to feel engaged, which can improve execution, just as responsibility. As a proprietor, in a perfect world you need employees who can think and follow up on their own, inside specific rules, so you don't generally need to look out for their shoulder to ensure work completes appropriately.

In any case, in huge associations, there can be a few layers of workers dependent on experience, timeframe with the organization, capacity to play out a particular assignment and different variables. Because of the decent variety of the workforce, the investigation demonstrated that while enabling employees can be positively effective, it can likewise have negative outcomes.

\section{RECOMMENDATIONS}

Following the discoveries in this investigation, the accompanying suggestions are advanced;

The examination prescribes that to improve execution, Mulago Refferal Hospital needs to attempt different advances and enhance certain parts of the workplace. Explicitly a real idea ought to be given to the establishment of structures for dealing with laborer discontent and course of action of adequate resources for every movement position.

Laborers' discontent directly affects their yield. The assessment shows that laborers were not content with the present plan of dealing with discontent. It is as such endorsed that another structure be set up to address the issues which were not being totally tended to by the present system. This would require the improvement of plan on dealing with agents' discontent in case there is none set up, and if it exists, by then a concentrated overview of the technique ought to be done.

Mulago Refferal Hospital further needs to address work selfsufficiency and open door for development and improvement for the all-around performed work jobs. Collaboration and designation of power enables workers to be set up for greater jobs. There is a requirement for a program to address designation and collaboration.

It is prescribed that all administrators ought to enhance their correspondence speed and mode. This should be possible by sorting out an instructional class on the adequacy of brief input to the general execution of the association just as different parts of correspondence. 


\section{SUGGESTIONS FOR FURTHER RESEARCH}

The study showed that all the both burnout and performance have no impact on the employee performance meaning there are other factors affecting their performance such as in 2017 the employees held a strike over there payment. Earlier on I mentioned the hospital having 1500 beds and three maternity wards and yet the population of Uganda is over forty million people implying there is lack of resources. The World Health Organization stated that a year one nurse is supposed to attend to 1000 patients implying a nurse should work on approximately five patients a day or there shift this shows there will be better services offered well as in Uganda a nurse works on almost 20000 patients a year meaning a day he or she works on almost 20 patient's that's exhaustion and all patients have different problems.

\section{DECLARATION OF CONFLICT OF INTEREST}

The authors received no financial support for the research and/or authorship of this article. There is no conflict of interest.

\section{REFERENCES}

1. Lawler EE, Mohram SA, Ledford GE. Employee Involvement and Total Quality Management: Practices and Results in Fortune 1000 Companies. Jossey-Bass, San Francisco, CA; 1992.

2. Foster $\mathrm{G}$. Re-examining the returns to training. Journal of Human Resources, 2005; 40(2): 453-76.

3. Conger JA, Kanungo GN. The empowerment process: integrating theory and practice. Academy of Management Review, 2007; 13(3): 471-82.

4. Vogt P. Transfer to power, Credit Union Management, 1997: 44-5.

5. Blanchard, K. Empowerment of Academic and Non Academic Staff at a Local University. Out with the old and in with the new Incentive. Journal of Management, and Business \& Economic. 1997: 59-61.

6. Spirits LX. Impact of High Performance Human Resource Management Practices on Employee Job Satisfaction: An Empirical Analysis. Interdisciplinary Journal of Contemporary Research in Business, 1997; 4: 318-42.

7. Ettorre N. Doing yourself out of a job? How middle managers cope with empowerment. Employee Relations, 1997; 19(2): 147-59.
8. Tschohl KO. Employee Empowerment Programs Among International NGOs in the Public Health Sector in Kenya. Unpublished MBA Thesis, University of Nairobi; 1997.

9. Troyer RB. Tips for Developing and Testing Questionnaires/ Instruments. Journal of Extension, 1997; 45(1).

10. Leitch T, Menon ST. Employee Empowerment: Definition, Measurement and Construct Validation, McGill University, Montreal, 1995.

11. Argyris MS. Impact of Leader's Change-Promoting Behavior on Readiness for Change: A Mediating Role of Organizational Culture. Journal of Management Sciences, 1998; 1(2): 102-23.

12. Enander F, Pastor J. Empowerment: what it is and what it's not. Empowerment in Organizations, 1996; 4(2): 5-7. (doi: 10.1108/09684899610118028).

13. Mohrman SA, Ledford GE. Employee Involvement and Total Quality Management Practices and Results in Fortune 1000 Companies, Jossey- Bass Publishers, San Francisco, CA, 1996.

14. Mallak A, Tyilana X. The Impact of Motivation on Job Satisfaction among Employees of a National Broadcaster, Dissertation Thesis of MasterDegree, University of Johannesburg, South Africa; 1996.

15. Wever C, Richard MR, Youngmee K, Ulas K. Differentiating Autonomy from Individualism and Independence: A SelfDetermination Theory Perspective on Internalization of Cultural Orientations and Well-Being. Journal of Personality and Social Psychology, 1993; 84(1): 97-110. (doi: 10.1037/0022-3514.84.1.97).

16. Sparrowe RT. The effects of organizational culture and leader member exchange on employee empowerment in the hospitality industry. Hospitality Research Journal, 1994; 18-19(3-1): 95-109. (doi: 10.1177/109634809401819003-109).

17. Story E. Patterns of empowerment and leadership style in project environment. International Journal of Project Management, 2010; 28(7): 638-49. (doi: 10.1016/j.ijproman.2009.11.013). 
18. Parker LE, Price RH. Empowered managers and empowered workers: the effects of managerial support and managerial perceived control on workers 'sense of control over decision making. Journal of Human Relations, 1994: 47(8): 911-28. (doi: 10.1177/001872679404700803).

19. Kanter RM. Men and Women of the Corporation. New York: Basic Books. 1977.

20. Izraeli DN. Sex effects or structural effects? An empirical test of Kanter's theory of proportions. Social Forces, 1993; 62(1): 153-65. (doi: 10.1093/sf/62.1.153).

21. Mondros JB, Wilson SM. Organizing for Power and Empowerment. Colombia University Press, New York, N.Y; 1994.

22. Heathfield C. A Global and Entrepreneurial Perspective (13th edition). McGraw Hall New York; 2007.

23. Collinson DL, Hearn J. Naming men as men: Implications for work, organization and management. Gender, Work and Organization, 1994; 1(1): 2-22. (doi: 10.1111/j.14680432.1994.tb00002.x).

24. Milliam ER., Russ DE. Executive commentaryempowerment a matter of degree? Academy of Management Executive, 1995; 9(3): 21-31.

25. Rosenthal P, Hill S, Peccei R. Checking out service: evaluating excellence, HRM, and TQMin retailing. Work, Employment and Society, 1997; 11(3): 481-503. (doi: 10.2307/23746226).

26. Sultana A, Irum S, Ahmed K, Mehmood N. Impact of Training on Employee Performance: A Study of Telecommunication Sector in Pakistan. Interdisciplinary Journal of Contemporary Research in Business, 2012; 4(6): 646-61.

27. Taborda A. Collins English Dictionary (21st Century Edition, 5th edition), Harper Collins Publishers; 2000.

28. Pines E, McLaney EJ. Business Finance for Decision Makers. London: Pitman Publishing ISBN:1981. P. 6

29. Spreitzer GM. Psychological empowerment in the workplace: dimensions, measurement, and validation. Academy of Management Journal, 1995; 38(5): 1442-65.

30. Lundy $M$, Younger B. Women in the workplace and employee assistance program. New York: The Haworth Press, Inc; 1994.
31. Landuyt NG. Employee perceptions of organizational quality and learned helplessness in higher education. Unpublished Doctoral Dissertation, University of Texas; 1999.

32. Miller PA, Goddard P, Laschinger HKS. Evaluating physical therapists' perception of empowerment using Kanter's theory of structural power in organizations. Physical Therapy, 2001; 81(12): 1880-8. (doi: 10.1093/ptj/81.12.1880).

33. Keller T, Dansereau F. Leadership and empowerment: a social exchange perspective. Hum. Rel, 1995; 48(2): 12746. (doi: 10.1177/001872679504800202).

34. Happy A. Blackwell Encyclopedia, Dictionary of Human Resource Management, Blackwell Publishers; 2004.

35. Glad B. Management Quality and Competitiveness, second edition, McGraw Hill; 2004.

36. Robbins SP. Organisational Behaviour (9th edition), Asoke K.Ghosh, prentice Hall; 2001.

37. Robbins SP, Judge A. Organisational Behaviour (13th edition), Prentice Hall New Jersey; 2002.

38. Psoinos A, Smithson S. Employee empowerment in manufacturing: A study of organization in the UK. New Technology, Work and Employment, 2002; 17(2): 132-48. (doi: 10.1111/1468-005X.00099).

39. Bakari TH. Relationship between employee empowerment and performance of city council of Nairobi (Unpublished MBA thesis), University of Nairobi; 2008.

40. Lwangasi MM. Relationship between empowerment and job satisfaction, a survey of employees in the nongovernmental sector in Kenya (Unpublished MBA Thesis), University of Nairobi; 2008.

41. Krejcie RV, Morgan DW. Determining Sample Size for Research Activities. Educational and Psychological Measurement, 1970; 30: 607-10.

42. Talip F, Rahman Z. Total Quality Management Implementation in the Healthcare Industry: A Proposed Framework. Proceedings of Second International Conference on Production and Industrial Engineering (CPIE-1985) organized by Department of Industrial and Production Engineering: 1985. 
43. Klagge J. The empowerment squeeze-views from the middle management position. Journal of management development, 1998; 17(8): 548-58. (doi: 10.1108/02621719810228407).

44. Amin ME. Social Science Research: Conception, Methodology and Analysis, Makerere University Printery, Kampala, Uganda. 2005.

45. Mugenda OM, Mugenda AG. Research Methodsquantitative and qualitative approaches. ACTS press, Nairobi, Kenya. 1999.

46. Trochim JG. Fiscal Space for Health in Uganda. World Bank Working Paper No. 186, Washington D.C; 2006.

47. Kanter RM. The change masters. New York: Simon \& Schuster; 1985.

48. Govule P, Mugisha JF, Katongole SP, Maniple E, Nanyingi $M$, Onzima RADDM. Application of workload indicators of staffing needs (WISN) in determining health workers' requirements for Mityana general hospital, Uganda. International Journal of Public Health Research, 1988; 3(5): 254-63.

49. Freudenberger HJ. Staff burn-out. Journal of Social Issues, 1974: 159-165.

50. Abramson LY, Seligman ME, Teasdale JD. Learned helplessness in humans: Critique and reformulation. Journal of Abnormal Psychology, 1978; 87(1): 49-74. (doi: 10.1037/0021-843X.87.1.49).

51. Schachter S, Singer J. Cognitive, social, and physiological determinants of the emotional state. Psychological Review, 1962; 69(5): 379-99. (doi: 10.1037/h0046234).

52. Maslach C. Job burnout new directions in research and intervention. Current directions in psychological science, 2003; 12(5): 189-92. (doi: 10.1111/1467-8721.01258).

53. Uysal MB. Musteri İliskileri departmanında çalışanların tükenmişlik düzeyleri: Bir banka çalısanları üzerinde bir araştırma [Burnout levels of employees in the Customer Relations department: A study on a bank employees] (Masters Thesis), Sakarya University, Social Sciences Institute, Sakarya; 2007.
54. Taycan O, Kutlu L, Cimen S, Aydın N. Bir üniversite hastanesinde çalışan hemşirelerde depresyon ve tükenmişlik düzeyinin sosyodemografik özelliklerle ilişkisi [Relationship between depression and burnout level and sociodemographic characteristics in nurses working in a university hospital]. Anadolu Psikiyatri Dergisi - Anatolian Journal of Psychiatry, 2006; 7(2): 1008.

55. Borman WC, Motowidlo S. Expanding the criterion domain to include elements of contextual performance. Personnel Selection in Organizations; San Francisco: Jossey-Bass; 1993: 71-98.

56. Bernardin HJ. Human resource management: An experiential approach. Irwin Professional Pub; 2002.

57. Kane JS. Performance distribution assessment; 1986.

58. Zimmerman MA. Taking aim on empowerment research: on the distinction between individual and psychological conceptions. American Journal of Community Psychology, 1990; 18: 169-77. (doi: 10.1007/BF00922695).

59. Mugenda OM, Mugenda AG. Research methods, qualitative and quantitative approach (Rev Ed). Centre for technology studies (ACTS) Press Nairobi, Kenya. (Rev. ed.); 2003.

60. Kapur R. Research Methodology; methods and techniques (2nd Edition), New Age international publishers, New Delhi: 2004.

61. Van C, Richard MR, Youngmee K, Ulas K. Differentiating Autonomy from Individualism and Independence: A SelfDetermination Theory Perspective on Internalization of Cultural Orientations and Well-Being. Journal of Personality and Social Psychology, 2003; 84: 97-110. (doi: 10.1037/0022-3514.84.1.97).

62. Dubrins SI. The challenges of Globalization to the Nigerian Industrial Sector. Nigerian Tribune December. 2009: 20-21. 